\title{
Effect of cobalt-mediated Toll-like receptor 4 activation on inflammatory responses in endothelial cells
}

\author{
Sami A. Anjum ${ }^{1, *}$, Helen Lawrence ${ }^{1,3, *}$, James P. Holland ${ }^{2,3}$, John A. Kirby ${ }^{1}$, David J. \\ Deehan $^{2,3}$ and Alison J. Tyson-Capper ${ }^{1}$ \\ ${ }^{1}$ Institute of Cellular Medicine, Newcastle University, Newcastle upon Tyne, UK \\ 2 Department of Orthopaedics, Freeman Hospital, Newcastle upon Tyne, UK \\ ${ }^{3}$ Northern Retrieval Centre, Freeman Hospital, Newcastle upon Tyne, UK \\ * Joint first authors \\ Correspondence to: Alison J. Tyson-Capper, email: alison.tyson-capper@ncl.ac.uk \\ Keywords: cobalt, TLR4, endothelium, inflammation, metal-on-metal, Immunology and Microbiology Section, Immune response, \\ Immunity \\ Received: July 15, 2016 \\ Accepted: November 02, 2016 \\ Published: November 09, 2016
}

\section{ABSTRACT}

Cobalt-containing metal-on-metal hip replacements are associated with adverse reactions to metal debris (ARMD), including inflammatory pseudotumours, osteolysis, and aseptic implant loosening. The exact cellular and molecular mechanisms leading to these responses are unknown. Cobalt ions $\left(\mathrm{Co}^{2+}\right)$ activate human Toll-like receptor 4 (TLR4), an innate immune receptor responsible for inflammatory responses to Gram negative bacterial lipopolysaccharide (LPS).

We investigated the effect of $\mathrm{CO}^{2+}$-mediated TLR4 activation on human microvascular endothelial cells (HMEC-1), focusing on the secretion of key inflammatory cytokines and expression of adhesion molecules. We also studied the role of TLR4 in $\mathrm{Co}^{2+}$-mediated adhesion molecule expression in MonoMac 6 macrophages.

We show that $\mathrm{Co}^{2+}$ increases secretion of inflammatory cytokines, including IL-6 and IL-8, in HMEC-1. The effects are TLR4-dependent as they can be prevented with a small molecule TLR4 antagonist. Increased TLR4-dependent expression of intercellular adhesion molecule 1 (ICAM1) was also observed in endothelial cells and macrophages. Furthermore, we demonstrate for the first time that $\mathrm{Co}^{2+}$ activation of TLR4 upregulates secretion of a soluble adhesion molecule, sICAM-1, in both endothelial cells and macrophages. Although sICAM-1 can be generated through activity of matrix metalloproteinase-9 (MMP-9), we did not find any changes in MMP9 expression following $\mathrm{Co}^{2+}$ stimulation.

In summary we show that $\mathrm{Co}^{2+}$ can induce endothelial inflammation via activation of TLR4. We also identify a role for TLR4 in $\mathrm{Co}^{2+}$-mediated changes in adhesion molecule expression. Finally, SICAM-1 is a novel target for further investigation in ARMD studies.

\section{INTRODUCTION}

Metal-on-metal (MoM) hip replacements are associated with the development of adverse reactions to metal debris (ARMD), which includes inflammatory pseudotumours, soft tissue necrosis, osteolysis and resulting aseptic implant loosening. Peri-implant tissues are often infiltrated by monocytes, macrophages and lymphocytes (referred to as aseptic lymphocyte-dominated vasculitis-associated lesion, ALVAL) which is indicative of an inflammatory response. However the cellular and molecular mechanisms that underlie ARMD are not wellunderstood.

$\mathrm{Co}^{2+}$ from MoM implants activates human Tolllike receptor 4 (TLR4) [1-3], an innate immune receptor expressed on immune cells as well as endothelial and epithelial cells. The major ligand for TLR4 is lipopolysaccharide from Gram negative bacteria, and 
receptor activation causes adaptor protein recruitment and an intracellular signalling cascade that upregulates the activity of transcription factors including NFאB [3].

We have previously shown that activation of TLR4 by $\mathrm{Co}^{2+}$ increases the secretion of inflammatory cytokines, including interleukin-8 (IL-8) and chemokine (C-X-C motif) ligand 10 (CXCL10), in MonoMac 6 macrophages [4]. Previous studies investigating the inflammatory effects of $\mathrm{Co}^{2+}$ in endothelial cells have primarily focused on endothelial cells transfected with TLR4 and its coreceptor MD2 $[3,5]$, but few studies have investigated the effect of $\mathrm{Co}^{2+}$ on endogenous TLR4-expressing endothelial cell lines. Endothelial cells are exposed to $\mathrm{Co}^{2+}$ present in the blood of MoM hip replacement patients [6] and therefore understanding the cellular response is important in defining the causes of ARMD and identifying potential therapeutic targets for ARMD prevention.

In the present study we assessed the immune response of endothelial cells to $\mathrm{Co}^{2+}$, with a focus on the role of TLR4. We also investigated the effect of $\mathrm{Co}^{2+}$ on adhesion molecule expression by endothelial cells and macrophages because of their critical role in inflammatory process such as leukocyte binding and extravasation.

\section{RESULTS}

\section{$\mathrm{Co}^{2+}$ activation of TLR4 increases IL-8 and IL-6 secretion}

HMEC-1 cells were stimulated with $0.25-1 \mathrm{mM}$ cobalt chloride hexahydrate $\left(\mathrm{Co}^{2+}\right)$ or $100 \mathrm{ng} / \mathrm{ml}$ LPS for $24 \mathrm{~h}$ and supernatant was collected for ELISA. IL-8 secretion was significantly increased by all concentrations of $\mathrm{Co}^{2+}$ (all $p<0.001$ except $0.25 \mathrm{mM}$ where $p=0.026$ ), peaking at $1300 \mathrm{pg} / \mathrm{ml}$ with $1 \mathrm{mM} \mathrm{Co}^{2+}$. The positive control LPS also increased IL-8 secretion (Figure 1A). IL-6 secretion was similarly upregulated by the agonists (all $p<0.001$ except $0.25 \mathrm{mM}$ where $p=0.011$ ) (Figure 1B).

To assess the role of TLR4 in the observed cytokine secretion, HMEC-1 were pre-incubated with $1 \mu \mathrm{g} / \mathrm{ml}$ CLI-095 (a small molecule TLR4 antagonist) for $6 \mathrm{~h}$ followed by stimulation with $0.75 \mathrm{mM} \mathrm{Co}^{2+}$ or $100 \mathrm{ng} /$ $\mathrm{ml}$ LPS for $24 \mathrm{~h}$. IL-8 and IL-6 secretion were measured by ELISA. Pre-treatment with CLI-095 significantly
A.

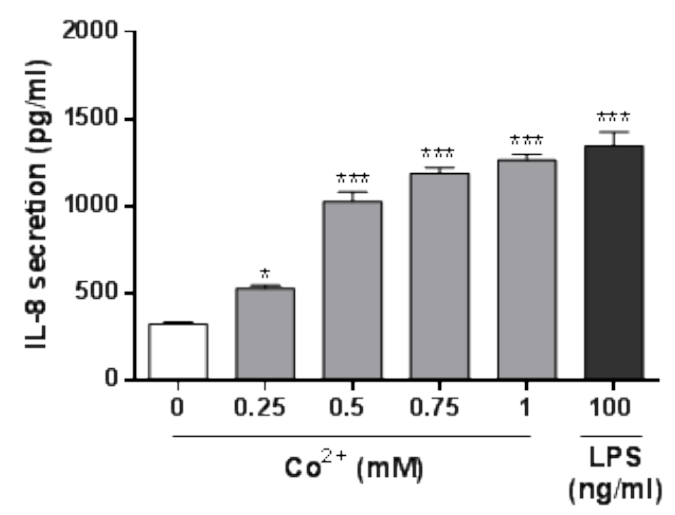

C.

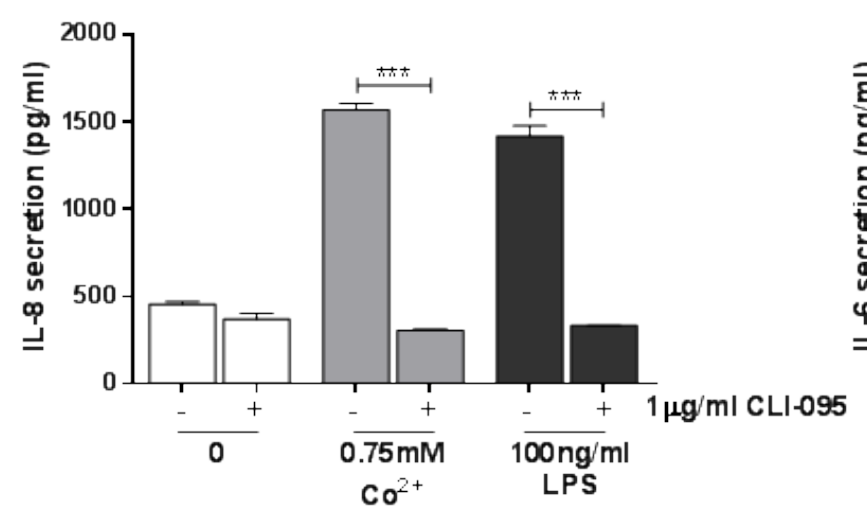

B.

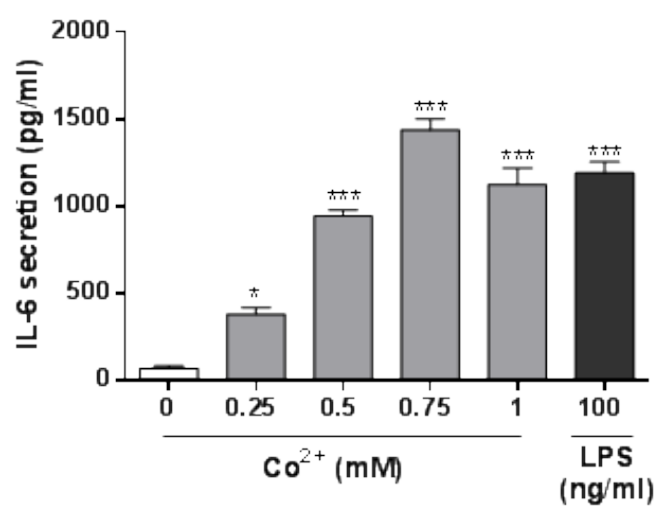

D.

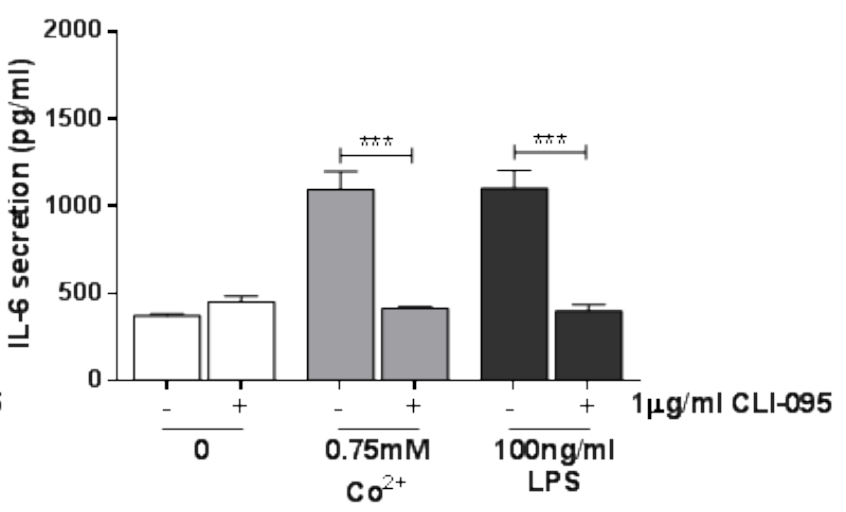

Figure 1: Effect of $\mathrm{Co}^{2+}$ ions and TLR4 activation on cytokine secretion by HMEC-1. A. \& B. HMEC-1 were stimulated with $0.25-1 \mathrm{mM} \mathrm{Co}{ }^{2+}$ or $100 \mathrm{ng} / \mathrm{ml}$ LPS. A. IL-8 and B. IL-6 secretion were assessed by ELISA. C. \& D. HMEC-1 were pre-treated with $1 \mu \mathrm{g} /$ $\mathrm{ml} \mathrm{CLI}-095$ followed by $24 \mathrm{~h}$ stimulation with $0.75 \mathrm{mM} \mathrm{Co}^{2+}$ or $100 \mathrm{ng} / \mathrm{ml} \mathrm{LPS}$. C. IL- 8 and D. IL-6 secretion was quantified by ELISA. All data is representative of three independent experiments. 
decreased secretion of both cytokines in response to $\mathrm{Co}^{2+}(p<0.001)$, showing that their release is TLR4dependent. The cytokine release was not a result of $\mathrm{Co}^{2+}$ mediated cytotoxicity as trypan blue staining revealed no change in HMEC-1 viability following cobalt stimulation (Supplementary Material, Figure 6).

A.

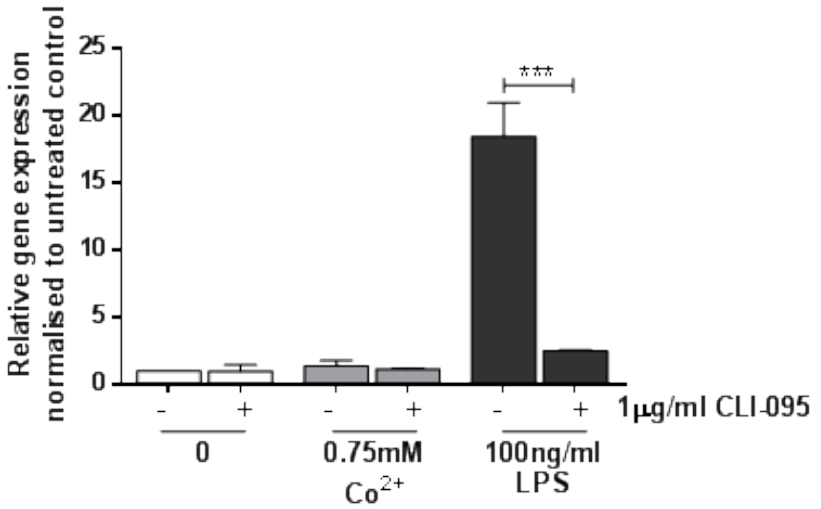

$\mathrm{Co}^{2+}$-mediated TLR4 activation increases ICAM1 expression in endothelial cells and macrophages

Endothelial cells are known to express adhesion molecules, including intercellular adhesion molecule-1

B.

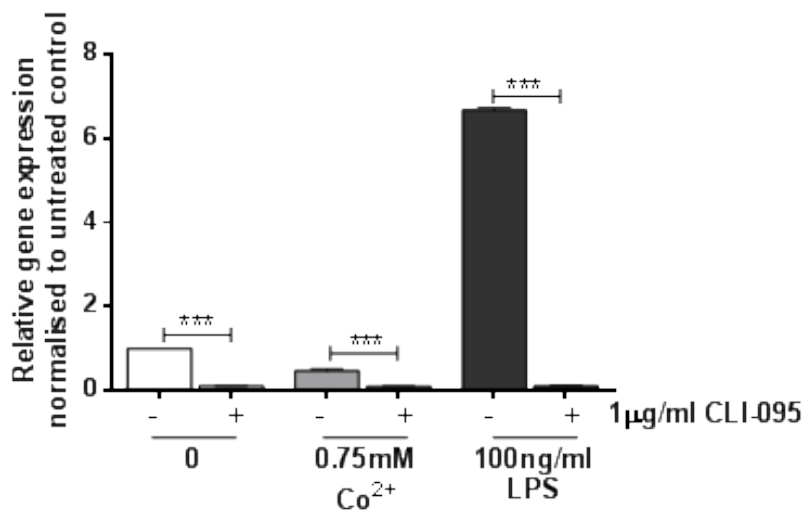

Figure 2: Effect of $\mathrm{Co}^{2+}$ and TLR4 activation on ICAM1 expression. A. HMEC-1 and B. MonoMac 6 cells were stimulated with $1 \mu \mathrm{g} / \mathrm{ml}$ CLI-095 for $6 \mathrm{~h}$ prior to $24 \mathrm{~h}$ stimulation with $0.75 \mathrm{mM} \mathrm{Co}^{2+}$ or $100 \mathrm{ng} / \mathrm{ml}$ LPS. RNA was isolated and cDNA synthesised by reverse transcription. ICAM1 expression was quantified by qRT-PCR. Data is representative of three independent experiments.

A.

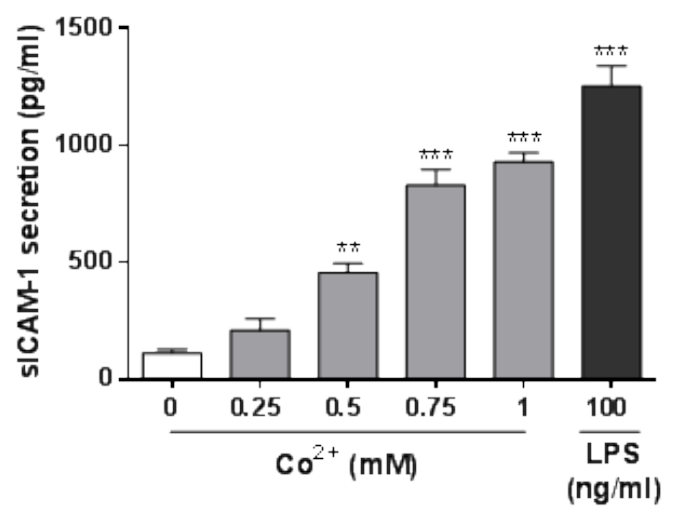

C.

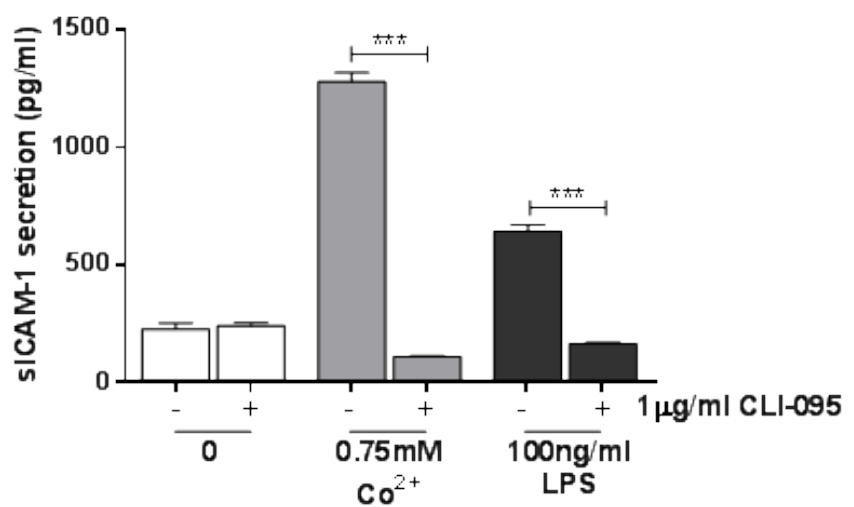

B.

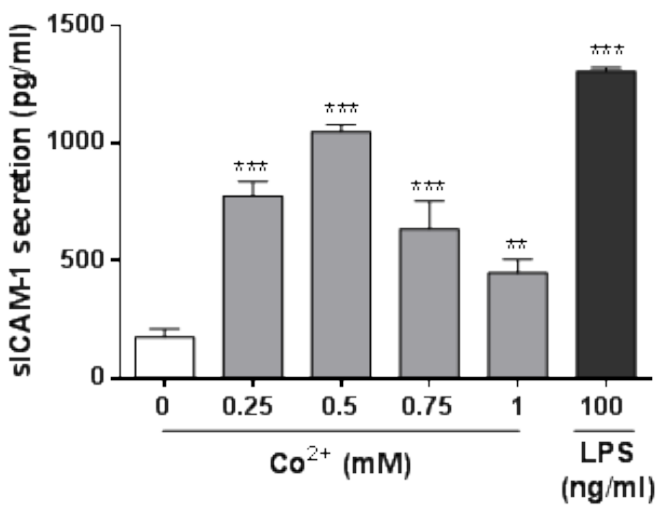

D.

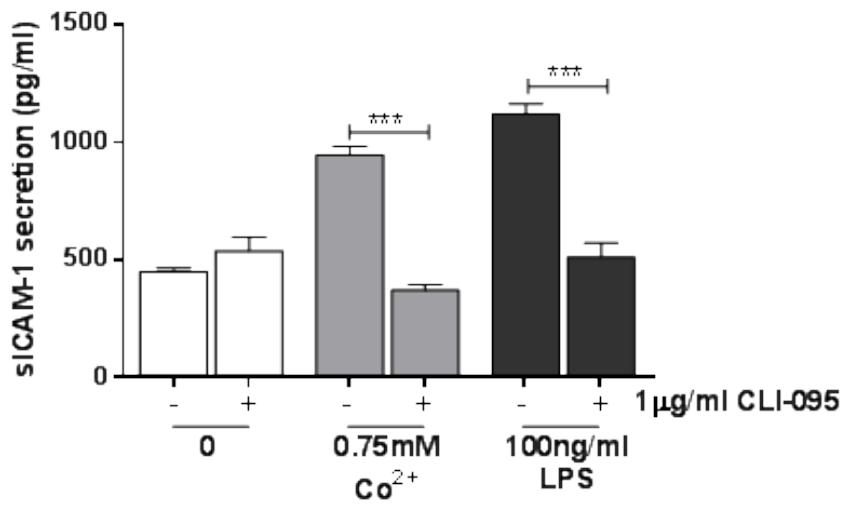

Figure 3: Effect of $\mathbf{C o}^{2+}$ and TLR4 activation on SICAM-1 secretion. A. HMEC-1 or B. MonoMac 6 cells were stimulated with $0.25-1 \mathrm{mM} \mathrm{Co}^{2+}$ for $24 \mathrm{~h}$ and sICAM-1 secretion was measured by ELISA. C. HMEC-1 or D. MonoMac 6 cells were pre-incubated with $1 \mu \mathrm{g} / \mathrm{ml} \mathrm{CLI}-095$ for $6 \mathrm{~h}$ before stimulation with $0.75 \mathrm{mM} \mathrm{Co}^{2+}$ or $100 \mathrm{ng} / \mathrm{ml}$ LPS. All data is representative of three independent experiments. 
(ICAM-1) and vascular adhesion molecule-1 (VCAM1), which are essential in leukocyte extravasation in inflammation. We assessed the effect of $\mathrm{Co}^{2+}$ activation of TLR4 on ICAM1 expression in HMEC-1 and MonoMac 6 macrophages. Macrophages also express CAMs for cellcell communication.

$\mathrm{Co}^{2+}$ induced a small but significant 3-fold upregulation in ICAMI expression by HMEC-1 ( $p=$ 0.013 ) (Figure 2A) and a larger 35-fold upregulation in MonoMac 6 cells $(p<0.001)$ (Figure 2B). In both cell lines the response was found to be TLR4-dependent because it was inhibited by the TLR 4 antagonist CLI-095 (both $p<0.001$ ).

\section{$\mathrm{Co}^{2+}$ increases secretion of SICAM-1 in a TLR4- dependent manner}

In addition to its membrane-bound form, ICAM1 can also be secreted as soluble ICAM-1 (sICAM-1). Given the TLR4-dependent increase in ICAMI expression described in Figure 2, we hypothesised that sICAM-1 release would also be affected by $\mathrm{Co}^{2+}$ Secretion of sICAM-1 by stimulated HMEC- 1 and MonoMac 6 cells was investigated by ELISA. Cells were stimulated with $0.25-1 \mathrm{mM} \mathrm{Co}^{2+}$ or $100 \mathrm{ng} / \mathrm{ml}$ LPS for $24 \mathrm{~h}$. In HMEC-1, sICAM-1 secretion was increased by $\mathrm{Co}^{2+}$ concentrations of $0.5 \mathrm{mM}$ and above (all $p<0.001$ ), peaking at $900 \mathrm{pg} / \mathrm{ml}$ with $1 \mathrm{mM} \mathrm{Co}^{2+}$ stimulation (Figure $3 \mathrm{~A}$ ). LPS increased sICAM-1 release to more than $1000 \mathrm{pg} / \mathrm{ml}(p<0.001)$. In MonoMac 6 cells sICAM-1 release was elevated across all $\mathrm{Co}^{2+}$ concentrations, peaking at $1000 \mathrm{pg} / \mathrm{ml}$ with $0.5 \mathrm{mM}$ treatment $(p<0.001)$ (Figure 3B). As in HMEC-1, LPS elicited more sICAM-1 release than $\mathrm{Co}^{2+}$.

HMEC-1 and MonoMac 6 cells were then preincubated with $1 \mu \mathrm{g} / \mathrm{ml}$ CLI-095 for $6 \mathrm{~h}$ followed by $24 \mathrm{~h}$ stimulation with either $0.75 \mathrm{mM} \mathrm{Co}^{2+}$ or $100 \mathrm{ng} / \mathrm{ml}$

A.

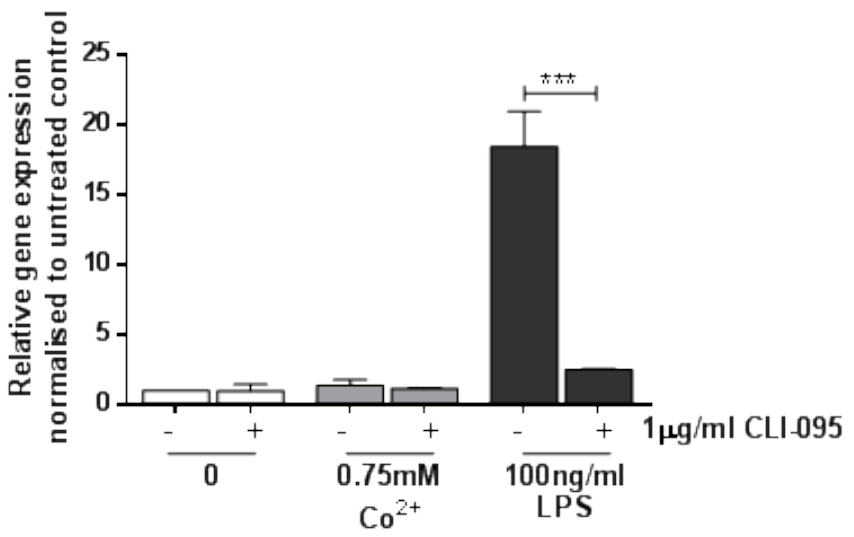

LPS. There was a significant decrease in $\mathrm{Co}^{2+}$ and LPSmediated sICAM-1 secretion in both HMEC-1 (Figure 3C) and MonoMac 6 cells (Figure 3D) ( $p<0.001$ in all cases). This shows that sICAM-1 release in response to $\mathrm{Co}^{2+}$ and LPS is TLR4-dependent.

\section{$\mathrm{Co}^{2+}$-mediated sICAM-1 secretion is not a result of MMP-9 activity}

Previous studies have shown that sICAM-1 can be produced when mICAM-1 is cleaved by the gelatinase matrix metalloprotease-9 (MMP-9) [7]. LPS stimulates MMP-9 activity through activation of TLR4. We therefore investigated whether or not $\mathrm{Co}^{2+}$ activation of TLR4 also increases MMP-9 expression. HMEC-1 and MonoMac6 cells were pre-treated with $1 \mu \mathrm{g} / \mathrm{ml} \mathrm{CLI-095}$ for $6 \mathrm{~h}$ followed by $24 \mathrm{~h}$ stimulation with $0.75 \mathrm{mM} \mathrm{Co}^{2+}$ or $100 \mathrm{ng} /$ $\mathrm{ml}$ LPS. MMP9 expression was assessed using qRT-PCR.

HMEC-1 exhibited a significant 16-fold increase in $M M P 9$ expression following stimulation with $100 \mathrm{ng} /$ $\mathrm{ml}$ LPS $(p<0.001)$ (Figure 4A). This was inhibited by CLI-095, showing that it is a TLR4-dependent effect $(p<0.001)$. In contrast there was no change in $M M P 9$ expression in response to $\mathrm{Co}^{2+}(p=0.999)$ (Figure 4A). A similar pattern was observed in MonoMac 6 cells; following LPS stimulation there was a 7-fold increase in $M M P 9$ expression by $(p<0.001)$ (Figure 4B). CLI095 inhibited this upregulated expression, showing that it is TLR4-dependent. However there was no increase in $M M P 9$ expression in response to $\mathrm{Co}^{2+}$, although CLI-095 decreased its expression further.

\section{DISCUSSION}

In the present study we describe a TLR4-dependent inflammatory response to $\mathrm{Co}^{2+}$ in human endothelial cells

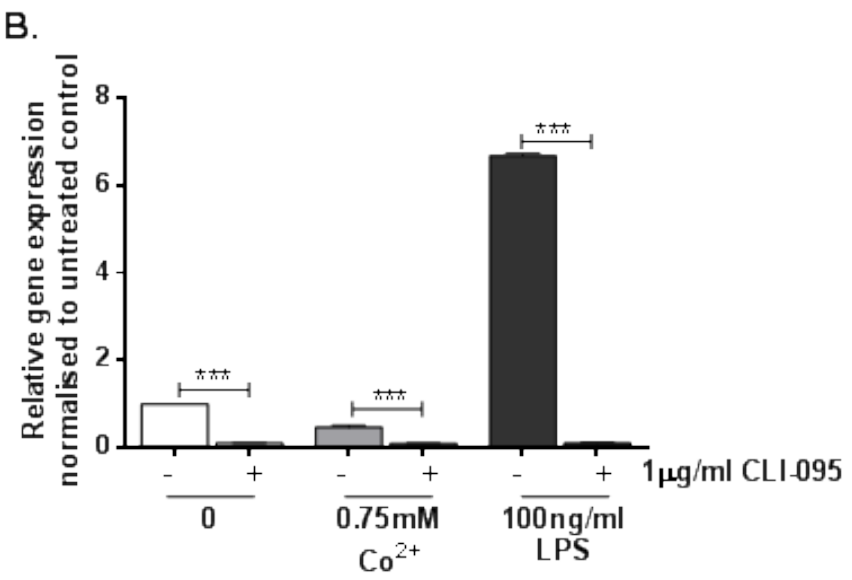

Figure 4: Effect of $\mathbf{C o}^{2+}$ and LPS on MMP9 expression. A. HMEC-1 or B. MonoMac6 cells were pre-treated with $1 \mu \mathrm{g} / \mathrm{ml}$ CLI095 for $6 \mathrm{~h}$ prior to stimulation with $0.75 \mathrm{mM} \mathrm{Co}^{2+}$ or $100 \mathrm{ng} / \mathrm{ml}$ LPS for $24 \mathrm{~h}$. MMP9 expression was assessed by qRT-PCR. All data is representative of at least two independent experiments. 
and macrophages. HMEC-1 exhibited significant increases in secretion of inflammatory cytokines IL- 8 and IL- 6 when stimulated with $\mathrm{Co}^{2+}$. This was inhibited by the TLR4 antagonist CLI-095, showing that the receptor is central to the responses. Previous studies have shown that $\mathrm{Co}^{2+}$ upregulates adhesion molecule expression [8-10], but have not demonstrated the exact signalling pathways involved. The data obtained in this study supports the findings of these studies and also indicates a previously unidentified role for TLR4 in $\mathrm{Co}^{2+}$-mediated ICAM1 expression in both endothelial cells and macrophages. Furthermore, for the first time a soluble adhesion molecule, sICAM-1, was detected in conditioned media from $\mathrm{Co}^{2+}$ and LPSstimulated HMEC-1 and MonoMac 6 cells. CLI-095 inhibited sICAM-1 changes and consequently they are TLR4-dependent.

We investigated the effect of $\mathrm{Co}^{2+}$ on $M M P 9$ expression because MMP-9 can cleave membranebound ICAM-1 resulting in the release of its soluble form, sICAM-1. In addition, MMP-9 can be regulated by
LPS activation of TLR4 [11] and therefore it is possible that $\mathrm{Co}^{2+}$-mediated TLR4 activation results in MMP-9 activity and sICAM-1 generation. However, although LPS increased MMP9 expression in a TLR4-dependent manner, there was no change in expression in response to $\mathrm{Co}^{2+}$. The absence of any effect was consistent between HMEC-1 and MonoMac 6 cells. The lack of change in MMP9 expression following $\mathrm{Co}^{2+}$ stimulation suggests that the enzyme is not responsible for the changes in sICAM-1 secretion observed in response to $\mathrm{Co}^{2+}$. Other proteolytic enzymes potentially involved in sICAM-1 cleavage include serine proteases [12], neutrophil elastase [13], and cathepsin G [14]. However the effect of $\mathrm{Co}^{2+}$ on these factors remains to be elucidated.

sICAM-1 has previously been proposed as a marker of inflammation [15] that is cleaved to regulate inflammatory responses but studies are now reporting a broader role for sICAM-1, including promotion of angiogenesis and neovascularisation [16]. This is of particular interest to the present study because blood vessel
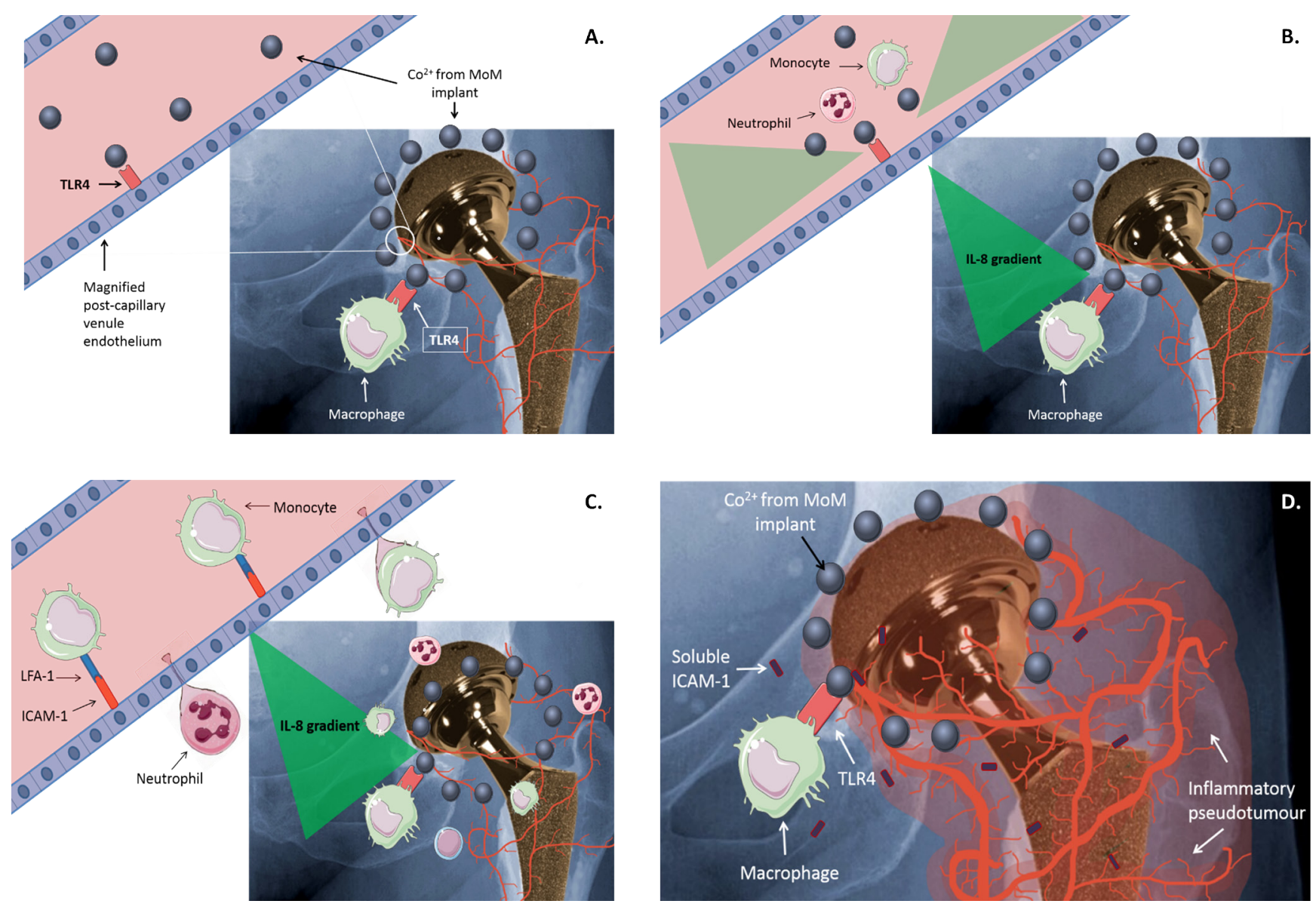

Figure 5: Working model. A. $\mathrm{Co}^{2+}$ released from metal-on-metal (MoM) hip implants activates TLR4 on immune cells such as macrophages. B. $\mathrm{Co}^{2+}$-mediated TLR4 activation results in the release of inflammatory cytokines and chemokines, including IL-8, by macrophages and endothelial cells. The generated cytokine/chemokine gradient attracts circulating leukocytes, such as monocytes and neutrophils. C. $\mathrm{Co}^{2+}$ activation of TLR4 on endothelial cells increases expression of ICAM-1, which promotes leukocyte binding via interaction with LFA-1. This in turn drives leukocyte extravasation. D. Migrated leukocytes, together with sICAM-1 released by endothelial cells and macrophages, promote an inflammatory response that may contribute to inflammation and pseudotumour development around a MoM implant. 
formation is required for pseudotumour development, which is a major factor in ARMD. Soft tissue necrosis is also a common feature of ARMD and can result from vascular inflammation restricting oxygen supply to the tissues. The ability of $\mathrm{Co}^{2+}$ to cause an inflammatory response, including pro-inflammatory cytokine release, in endothelial cells may indicate that similar effects occur in vitro, which could result in ischaemia and subsequent tissue death.

A limitation of the present study is the high $\mathrm{Co}^{2+}$ concentrations that we have used to stimulate the cells. Even the concentrations at the lower end of the range are considerably higher than those detected in the serum and synovial fluid of patients with failed MoM implants [1719]. However, the $\mathrm{Co}^{2+}$ concentrations used in our study are in line with those of similar in vitro studies of the inflammatory effects of metal ions [3, 10, 20, 21]. Hence, they are appropriate and relevant for this study.

A working model of the possible mechanisms indicated by our results is shown in Figure 5. In summary, we have shown that $\mathrm{Co}^{2+}$ has the potential to induce an inflammatory response in the endothelium through activation of TLR4. It also shows for the first time that $\mathrm{Co}^{2+}$ increases SICAM-1 secretion in a TLR4-dependent manner. Although the exact mechanism of its release remains unclear, sICAM-1 is an interesting target for further investigation in ARMD because of its previously described roles in angiogenesis, neovascularisation and tumour formation [16].

\section{MATERIALS AND METHODS}

\section{Cell culture}

Human microvascular endothelial cells (HMEC-1) are derived from dermal foreskin. Cells were cultured in MCDB131 (Sigma-Aldrich, Gillingham, UK) medium supplemented with $10 \%$ foetal bovine serum (FBS), 50U/ $\mathrm{ml}$ penicillin, $50 \mu \mathrm{g} / \mathrm{ml}$ streptomycin, $10 \mathrm{ng} / \mathrm{ml}$ epidermal growth factor (EGF) and $1 \mu \mathrm{g} / \mathrm{ml}$ hydrocortisone (all Sigma-Aldrich).

MonoMac 6 cells are a human TLR4-expressing cell line derived from acute monocytic leukaemia. Cells were cultured as previously described [22].

\section{Cell stimulation}

Cells were stimulated with cobalt chloride hexahydrate (referred to as $\mathrm{Co}^{2+}$ in this study) in complete culture medium appropriate for each cell line. Complete culture medium was used as a negative control while 100ng/ml TLR4-specific LPS (Alexis Biochemicals, San Diego, USA) provided a positive control.

\section{ELISA (IL-8, IL-6, sICAM-1)}

Inflammatory cytokine secretion was quantified by enzyme-linked immunosorbent assay (ELISA). IL-6, IL-8 and sICAM-1 ELISA kits were purchased from Peprotech (London, UK) and assays performed as described previously [4].

\section{qRT-PCR}

Gene expression changes were assessed by quantitative reverse transcriptase polymerase chain reaction (qRT-PCR) using TaqMan primers and probes (ThermoFisher Scientific, Massachusetts, USA). RNA was isolated using a Qiagen RNeasy Mini kit (Qiagen, Venlo, Netherlands) and cDNA synthesised using Superscript III reverse transcriptase (ThermoFisher Scientific). Each qRTPCR reaction contained $5 \mu \mathrm{l}$ TaqMan Gene Expression Mastermix (ThermoFisher Scientific), $2 \mu$ l diluted cDNA template, $2.5 \mu \mathrm{l}$ nuclease-free $\mathrm{H}_{2} \mathrm{O}$ and $0.5 \mu \mathrm{l}$ TaqMan Gene Expression Assay (ThermoFisher Scientific). No template controls with nuclease-free $\mathrm{H}_{2} \mathrm{O}$ instead of cDNA were included. All reactions were performed in triplicate and target gene expression was normalised to $G A P D H$ expression.

\section{CLI-095}

Inhibition of TLR4 was performed by pre-incubating cells for $6 \mathrm{~h}$ with $1 \mu \mathrm{g} / \mathrm{ml}$ CLI-095. CLI-095 (Invivogen, UK) is a small molecule TLR4 antagonist that binds to the intracellular domain of the receptor and prevents recruitment of downstream adaptor proteins.

\section{Cytotoxicity assay}

Cytotoxicity was assessed by trypan blue staining. Stimulated cells were resuspended in a small volume of supernatant and $10 \mu \mathrm{l}$ cell suspension was mixed with $10 \mu 1$ trypan blue dye. Staining was visualised on a Luna II automated cell counter (Logos Biosystems, Virginia, USA)

\section{Statistical analysis}

Statistical significance was calculated using a oneway analysis of variance (ANOVA). When samples were compared to an untreated control (Figures 1A, 1B, 3A, and 3B), Dunnett's test for multiple comparisons was performed. When comparing all samples to each other, Tukey's test for multiple comparisons was performed. 


\section{CONFLICTS OF INTEREST}

There is no conflict of interest

\section{REFERENCES}

1. Tyson-Capper AJ, Lawrence H, Holland JP, Deehan DJ and Kirby JA. Metal-on-metal hips: Cobalt can induce an endotoxin-like response. Annals of the Rheumatic Diseases. 2013; 72(3):460-461.

2. Potnis PA, Dutta DK and Wood SC. Toll-like receptor 4 signaling pathway mediates proinflammatory immune response to cobalt-alloy particles. Cellular Immunology. 2013; 282(1):53-65.

3. Raghavan B, Martin SF, Esser PR, Goebeler M and Schmidt M. Metal allergens nickel and cobalt facilitate TLR4 homodimerization independently of MD2. EMBO Reports. 2012; 13(12):1109-1115.

4. Lawrence H, Deehan D, Holland J, Kirby J and TysonCapper A. The immunobiology of cobalt: Demonstration of a potential aetiology for inflammatory pseudotumours after metal-on-metal replacement of the hip. Bone and Joint Journal. 2014; 69B(9):1172-1177.

5. Oblak A, Pohar J and Jerala R. MD-2 determinants of nickel and cobalt-mediated activation of human TLR4. PLoS ONE. 2015; 10(3):e0120583.

6. Rodríguez De La Flor M, Hernández-Vaquero D and Fernández-Carreira JM. Metal presence in hair after metalon-metal resurfacing arthroplasty. Journal of Orthopaedic Research. 2013; 31(12):2025-2031.

7. Fiore E, Fusco C, Romero P and Stamenkovic I. Matrix metalloproteinase 9 (MMP-9/gelatinase B) proteolytically cleaves ICAM-1 and participates in tumor cell resistance to natural killer cell-mediated cytotoxicity. Oncogene. 2002; 21(34):5213-5223.

8. Caicedo MS, Pennekamp PH, McAllister K, Jacobs JJ and Hallab NJ. Soluble ions more than particulate cobalt-alloy implant debris induce monocyte costimulatory molecule expression and release of proinflammatory cytokines critical to metal-induced lymphocyte reactivity. Journal of Biomedical Materials Research - Part A. 2010; 93(4):13121321.

9. Goebeler M, Meinardus-Hager G, Roth J, Goerdt S and Sorg C. Nickel chloride and cobalt chloride, two common contact sensitizers, directly induce expression of intercellular adhesion molecule-1 (ICAM-1), vascular cell adhesion molecule-1 (VCAM-1), and endothelial leukocyte adhesion molecule (ELAM-1) by endothelial cells. Journal of Investigative Dermatology. 1993; 100(6):759-765.

10. Ninomiya JT, Kuzma SA, Schnettler TJ, Krolikowski JG, Struve JA and Weihrauch D. Metal Ions Activate Vascular Endothelial Cells and Increase Lymphocyte Chemotaxis and Binding. Journal of Orthopaedic Research. 2013; 31(9):1484-1491.
11. Li H, Xu H and Sun B. Lipopolysaccharide regulates MMP9 expression through TLR4/NF- $\mathrm{BB}$ signaling in human arterial smooth muscle cells. Molecular Medicine Reports. 2012; 6(4):774-778.

12. Mendez MP, Morris SB, Wilcoxen S, Du M, Monroy YK, Remmer H, Murphy H, Christensen PJ and Paine R, 3rd. Disparate mechanisms of sICAM-1 production in the peripheral lung: contrast between alveolar epithelial cells and pulmonary microvascular endothelial cells. Am J Physiol Lung Cell Mol Physiol. 2008; 294(4):L807-814.

13. Champagne B, Tremblay P, Cantin A and St. Pierre Y. Proteolytic cleavage of ICAM-1 by human neutrophil elastase. Journal of Immunology. 1998; 161(11):6398-6405.

14. Robledo O, Papaioannou A, Ochietti B, Beauchemin C, Legault D, Cantin A, King PD, Daniel C, Alakhov VY, Potworowski EF and St-Pierre Y. ICAM-1 isoforms: Specific activity and sensitivity to cleavage by leukocyte elastase and cathepsin G. European Journal of Immunology. 2003; 33(5):1351-1360.

15. Kovacs E. The serum levels of soluble intercellular adhesion molecule-1 (sICAM-1) and soluble gp130 (sgp130) in different tumour stages. Correlation between the two parameters in progression of malignancy. Biomedicine and Pharmacotherapy. 2005; 59(9):498-500.

16. Yong Song G, Kim PN, Li HC, Elkin M and Kleinman HK. Stimulation of tumor growth by human soluble intercellular adhesion molecule-1. Cancer Research. 2001; 61(10):42534257.

17. Langton DJ, Jameson SS, Joyce TJ, Webb J and Nargol AVF. The effect of component size and orientation on the concentrations of metal ions after resurfacing arthroplasty of the hip. Journal of Bone and Joint Surgery - Series B. 2008; 90(9):1143-1151.

18. Andrews RE, Shah KM, Wilkinson JM and Gartland A. Effects of cobalt and chromium ions at clinically equivalent concentrations after metal-on-metal hip replacement on human osteoblasts and osteoclasts: Implications for skeletal health. Bone. 2011; 49(4):717-723.

19. Kwon YM, Ostlere SJ, McLardy-Smith P, Athanasou NA, Gill HS and Murray DW. "Asymptomatic" Pseudotumors After Metal-on-Metal Hip Resurfacing Arthroplasty. Prevalence and Metal Ion Study. Journal of Arthroplasty. 2011; 26(4):511-518.

20. Rachmawati D, Bontkes HJ, Verstege MI, Muris J, Von Blomberg BME, Scheper RJ and Van Hoogstraten IMW. Transition metal sensing by Toll-like receptor-4: Next to nickel, cobalt and palladium are potent human dendritic cell stimulators. Contact Dermatitis. 2013; 68(6):331-338.

21. Schmidt M, Raghavan B, Muller V, Vogl T, Fejer G, Tchaptchet S, Keck S, Kalis C, Nielsen PJ, Galanos C, Roth J, Skerra A, Martin SF, Freudenberg MA and Goebeler M. Crucial role for human Toll-like receptor 4 in the development of contact allergy to nickel. Nature Immunology. 2010; 11(9):814-819. 
22. Lawrence H, Mawdesley A, Holland J, Kirby J, Deehan D and Tyson-Capper A. Targeting Toll-like receptor 4 prevents cobalt-mediated inflammation. Oncotarget. 2016; 7(7):7578. doi: 10.18632/oncotarget.7105. 